\title{
Voltage opens unopposed gap junction hemichannels formed by a connexin 32 mutant associated with $\mathrm{X}$-linked Charcot-Marie-Tooth disease
}

\author{
C. K. Abrams*, M. V. L. Bennett, V. K. Verselis, and T. A. Bargiello \\ Department of Neuroscience, Albert Einstein College of Medicine, 1300 Morris Park Avenue, Bronx, NY 10461
}

Contributed by M. V. L. Bennett, December 31, 2001

The X-linked form of Charcot-Marie-Tooth disease (CMTX) is an inherited peripheral neuropathy that arises in patients with mutations in the gene encoding the gap junction protein connexin 32 (Cx32), which is expressed by Schwann cells. We recently showed that Cx32 containing the CMTX-associated mutation, Ser-85-Cys (S85C), forms functional cell-cell channels in paired Xenopus oocytes. Here, we describe that this mutant connexin also shows increased opening of hemichannels in nonjunctional surface membrane. Open hemichannels may damage the cells through loss of ionic gradients and small metabolites and increased influx of $\mathrm{Ca}^{2+}$, and provide a mechanism by which this and other mutant forms of Cx32 may damage cells in which they are expressed. Evidence for open hemichannels includes: (i) oocytes expressing the Cx32(S85C) mutant show greatly increased conductance at inside positive potentials, significantly larger than in oocytes expressing wildtype Cx32 (Cx32WT); and (ii) the induced currents are similar to those previously described for several other connexin hemichannels, and exhibit slowly developing increases with increasing levels of positivity and reversible reduction when intracellular $\mathrm{pH}$ is decreased or extracellular $\mathrm{Ca}^{2+}$ concentration is increased. Although increased currents are seen, oocytes expressing Cx32(S85C) have lower levels of the protein in the surface and in total homogenates than do oocytes expressing Cx32WT; thus, under the conditions examined here, hemichannels in the surface membrane formed of the $\mathrm{Cx32}$ (S85C) mutant have a higher open probability than hemichannels formed of Cx32WT. This increase in functional hemichannels may damage Schwann cells and ultimately lead to loss of function in peripheral nerves of patients harboring this mutation.

he X-linked form of Charcot-Marie-Tooth disease (CMTX) is an inherited peripheral neuropathy that arises in patients with mutations in the gene encoding the gap junction protein connexin 32 (Cx32) (1). Cx32 is found in myelinating Schwann cells, where it is believed to form channels between adjacent myelin loops at the Schmidt-Lantermann incisures and in the paranodal regions (2). Cx32 also has recently been demonstrated in primary cultures of Schwann cells (3). In the myelinating Schwann cell, reflexive gap junctions should shorten the diffusion distance between the Schwann cell nucleus and adaxonal cytoplasm $\approx 350$-fold in a $10-\mu \mathrm{m}$ diameter axon (4). Second messengers such as cAMP, $\mathrm{Ca}^{2+}$, and $\mathrm{IP}_{3}$ permeate wild-type Cx32 (Cx32WT) junctions (5, 6), and normal function of the axon Schwann cell unit may depend on communication through the reflexive pathway.

Several lines of evidence suggest that loss of Cx32 function is sufficient to cause CMTX. First, several CMTX mutations are predicted to lead to either no expression of protein e.g., mutations in the promoter region (7) or very truncated forms of the protein, such as R22STOP (8). Second, two families with a complete loss of the coding portion of $\mathrm{Cx} 32$ have recently been described, and the disease in these cohorts is very similar to that seen in other moderately or severely affected patients (9-11). Third, several other mutations lead to either no or very little detectable protein when expressed exogenously (12). Fourth,

many mutants show alterations in their functional properties which would be predicted to lead to a complete or partial loss of coupling $(13,14)$.

There is evidence that a (toxic) gain of function model can explain the pathogenesis of CMTX caused by some mutations. First, abnormalities in trafficking of several mutants lead to accumulation of protein in the cytoplasm of transfected mammalian cell lines expressing these proteins (12). Deschenes et al. (14) suggest that this accumulation, in turn, may lead to interference with trafficking of other essential proteins. However, three of three mutant proteins examined were shown to be efficiently removed by the cellular quality control apparatus. Second, transgenic mice expressing the R142W mutation in the presence of Cx32WT develop a demyelinating neuropathy (15). Third, the coinjection of mRNA for Cx32(R142W) and wild-type (WT) Cx26 in paired Xenopus oocytes leads to lower levels of Cx26-mediated intercellular communication than in paired oocytes injected with Cx26WT alone or in combination with Cx32WT (16).

Because open hemichannels in nonjunctional membrane were thought likely to have permeability properties similar to those of the intercellular channels, it was generally assumed that, under physiological conditions, "unapposed" hemichannels were closed to prevent metabolic stress and death caused by the collapse of ionic gradients, loss of small metabolites, and influx of $\mathrm{Ca}^{2+}$ (see, for example, ref. 17). However, multiple observations in a diverse set of preparations now support the existence of functional connexin hemichannels (18-39). Evidence supporting the existence of functional hemichannels includes: $(i)$ cells are permeable to molecules to which gap junctions are permeable but are not permeable to larger molecules, which would indicate loss of membrane integrity; (ii) gap junction blockers reduce this permeability; (iii) cells not expressing connexins do not show this permeability; and (iv) patch clamp recordings demonstrate single channels with appropriate properties.

In this article, we describe a mechanism, namely opening of hemichannels, by which a mutation in Cx32 may damage cells in which it is expressed and contribute to the pathogenesis of CMTX. We recently demonstrated (13) that connexins containing a Cys instead of a Ser at position 85 (S85C) in the predicted second transmembrane domain of $\mathrm{Cx} 32$ form functional cell-cell channels in paired Xenopus oocytes (13). Here, we show that expression of this CMTX-associated mutant (40) in single oocytes leads to large, relatively nonselective, voltage-dependent currents not seen in oocytes expressing Cx32WT. This finding suggests that in this preparation, the Cx32(S85C) mutant has a

Abbreviations: CMTX, X-linked form of Charcot-Marie-Tooth disease; Cx32, connexin 32; Cx32WT, wild-type Cx32; antiCx38, antisense oligonucleotide to connexin 38 .

*To whom reprint requests should be addressed. E-mail: mmfreidi@ix.netcom.com.

The publication costs of this article were defrayed in part by page charge payment. This article must therefore be hereby marked "advertisement" in accordance with 18 U.S.C. $\S 1734$ solely to indicate this fact. 
much greater propensity to form conducting hemichannels than does Cx32WT. The resulting increase in membrane permeability may prevent normal functioning of the Schwann cells and peripheral nerves of patients harboring this mutation.

\section{Methods}

Production of Mutants. The Cx32(S85C) mutant was produced by oligonucleotide-directed PCR using the human Cx32 gene (4) as the primer. The PCR product then was cloned into the human gene for $\mathrm{Cx} 32$ by using unique flanking restriction sites. Clones were screened by restriction digestion and sequenced by using primers encompassing the entire cloned PCR product and flanking restriction sites.

In Vitro Transcription of RNA for Expression in Oocytes. RNA was transcribed by using the Message-Machine kit with T7 RNA polymerase (Ambion, Austin, TX) according to manufacturer's instructions. RNA was column purified and eluted in nucleasefree $\mathrm{H}_{2} \mathrm{O}$ containing an antisense phosphorothioate oligonucleotide complementary to $\mathrm{Cx} 38$ (AntiCx38) at a concentration of $0.3 \mathrm{pmol} / \mathrm{nl}$. Cx38 is the major endogenous gap junction protein in oocytes; the antisense oligonucleotide that was used blocks all endogenous coupling between paired oocytes within 48-72 h (V.V., unpublished observations). AntiCx38 at a concentration of $0.3 \mathrm{pmol} / \mathrm{nl}$ was included in all injections described in this paper; for clarity, explicit reference to it will be made only when it was injected alone as a control for the mRNA containing injections. RNA quality was evaluated by gel electrophoresis, and concentration was quantitated by absorbance at $260 \mathrm{~nm}$ and evaluation of relative intensity on ethidium-stained agarose gels. The RNA then was diluted as needed, divided into aliquots for single use, and stored at $-70^{\circ} \mathrm{C}$.

Oocyte Preparation and Injection. Xenopus oocytes were harvested and prepared as described (41). Cells were allowed to rest $6 \mathrm{~h}$ at $18^{\circ} \mathrm{C}$ in MND96 with $\mathrm{Ca}^{2+}(96 \mathrm{mM} \mathrm{NaCl} / 2 \mathrm{mM} \mathrm{KCl} / 2 \mathrm{mM}$ $\mathrm{MgCl}_{2} / 2.5 \mathrm{mM}$ Na-pyruvate/ $1.8 \mathrm{mM} \mathrm{CaCl}_{2} / 5 \mathrm{mM}$ Hepes, $\mathrm{pH}$ 7.6) and then injected with $0.1 \mu \mathrm{l}$ of a solution containing 0.06 to $0.35 \mu \mathrm{g} / \mu \mathrm{l}$ of RNA and $0.3 \mathrm{pmol} / \mathrm{hl}$ of antisense oligonucleotide to $\mathrm{Cx} 38$ in nuclease-free $\mathrm{H}_{2} \mathrm{O}$. For experiments to measure conductance, RNA concentration was $0.175 \mu \mathrm{g} / \mu \mathrm{l}$ unless otherwise noted, and measurements of were made between 22 and $28 \mathrm{~h}$ after injection.

Oocyte in Vivo Expression and Two-Electrode Voltage Clamping. Membrane conductance was measured by a two-electrode voltage clamp as described (42). Unless otherwise specified, the bath solution was MND96 with $\mathrm{Ca}^{2+}$. For experiments involving changes in bath solution, oocytes were placed in a small volume chamber to ensure that volume exchanges occurred in less than $5 \mathrm{~s}$. Data were collected by using the PCLAMP data acquisition program (Axon Instruments, Foster City, CA) and LABMASTER/ TL-1 software; filtering was at $100 \mathrm{~Hz}$. Current-voltage relations were produced by measuring the peak membrane currents at the end of $20 \mathrm{~s}$ positive pulses and subtracting the instantaneous currents seen at the onset of the pulse. Analysis of the data and the conclusions presented here were not affected when data were analyzed without subtracting instantaneous currents.

Western Blot Analysis of Oocytes Protein Extracts. Oocytes (15-20) injected with mRNA for Cx32WT, Cx32(S85C), or antiCx38 alone were washed twice in PBS, and surface proteins were biotinylated with the membrane-impermeant reagent, sulfosuccinimidyl 2-(biotinamido) ethyl-1,3' dithiopropionate (sulfoNHS-SS-biotin; Pierce) for $30 \mathrm{~min}$ at $4^{\circ} \mathrm{C}$ as described (43). Thirteen intact oocytes then were separated, washed twice in PBS, homogenized on ice in buffer containing $100 \mathrm{mM} \mathrm{NaCl}, 20$ $\mathrm{mM}$ Tris $\cdot \mathrm{HCl}, 1 \%$ Triton $\mathrm{X}-100$, and $0.25 \mathrm{mg} / \mathrm{ml}$ protease
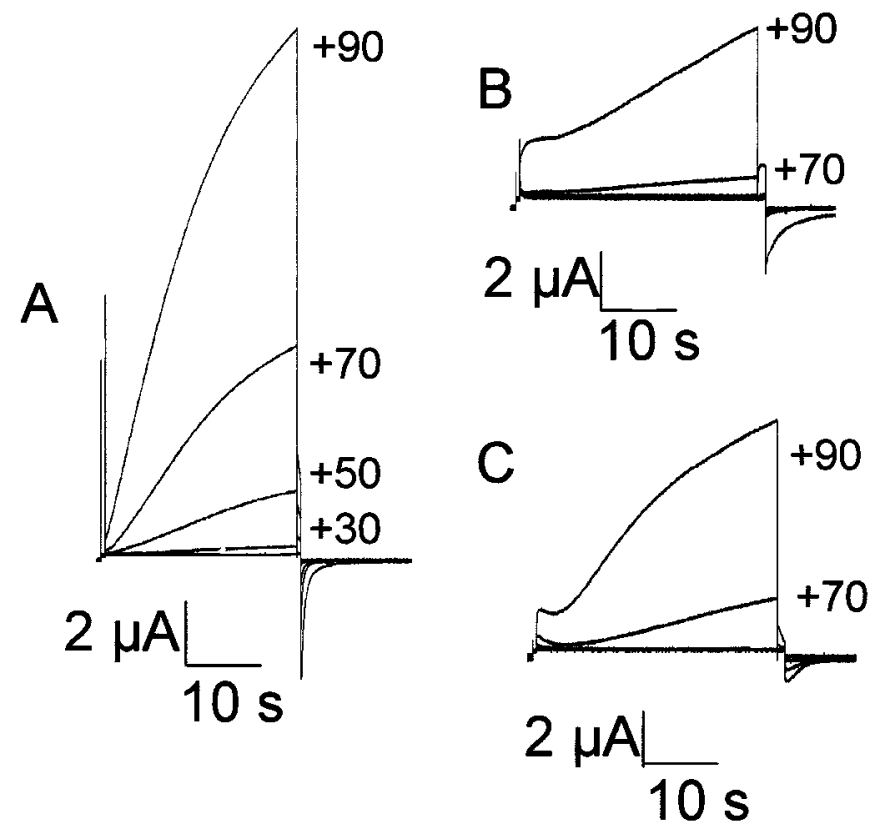

Fig. 1. Representative current traces for oocytes injected with either $0.1 \mu \mathrm{l}$ of a $175 \mathrm{ng} / \mu$ l solution of mRNA for Cx32(S85C) (AntiCx38) (A), mRNA for Cx32WT $(B)$, or antiCx38 alone $(C)$. Currents evoked by depolarizing the $\mathrm{Cx32}$ (S85C)-injected cells were larger and activated at smaller voltages than did those from either the Cx32WT- or antiCx38-injected cells. Traces in $20 \mathrm{mV}$ increments from $+10 \mathrm{mV}$ to $+90 \mathrm{mV}$ for Cx32(S85C) and $+30 \mathrm{mV}$ to $+90 \mathrm{mV}$ for Cx32WT and antiCx38 are shown.

inhibitor mixture P2714 (Sigma) and centrifuged at 13,000 $\times g$ at $4^{\circ} \mathrm{C}$, after which the pellet was discarded. Plasma membrane biotinylated proteins were isolated by incubating extracts with Neutravidin-linked beads (Pierce) for $2 \mathrm{~h}$ at $4^{\circ} \mathrm{C}$, followed by centrifugation and extensive washes with PBS. Bound proteins were eluted from beads by incubation with sample buffer containing $100 \mathrm{mM}$ DTT, which cleaves the disulfide bond in the linker between the protein and biotin bound to the beads. Forty microliters of membrane protein solution and 5-20 $\mu \mathrm{g}$ of each total protein extract diluted with sample buffer were loaded onto an SDS/12\% polyacrylamide gel, electrophoresed, and transferred to a poly(vinylidene difluoride) membrane by using a semidry electroblot unit. Dye-labeled molecular weight markers were run with each gel as molecular weight standards and to confirm transfer. The membranes then were probed with mouse anti-Cx32 (1:1,000; \#C6344, Sigma) in conjunction with the Western Breeze chromogenic detection system (Invitrogen) and air-dried for storage. Because the anti-Cx32 antibody was raised to a peptide containing residues 106-124 from the cytoplasmic loop of the protein, and because residue 85 is in the center of the second predicted transmembrane domain, there should be no difference in the sensitivity of labeling for Cx32WT and Cx32(S85C).

\section{Results}

Large, slowly activating outward currents were consistently induced when oocytes injected with mRNA for the Cx32(S85C) mutant were stepped to voltages greater than $+10 \mathrm{mV}$; the currents increased with increasing levels of depolarization (Fig. $1 A$ ). Oocytes injected with mRNA for Cx32WT (Fig. 1B) or with antiCx38 alone (Fig. 1C) showed similar but higher threshold currents that activated only at voltages above $+50 \mathrm{mV}$. The currents produced in the Cx32(S85C)-injected oocytes had a reversal potential of about $-15 \mathrm{mV}$ (data not shown) when MND96 with $\mathrm{Ca}^{2+}$ was the bath solution, suggesting that the 


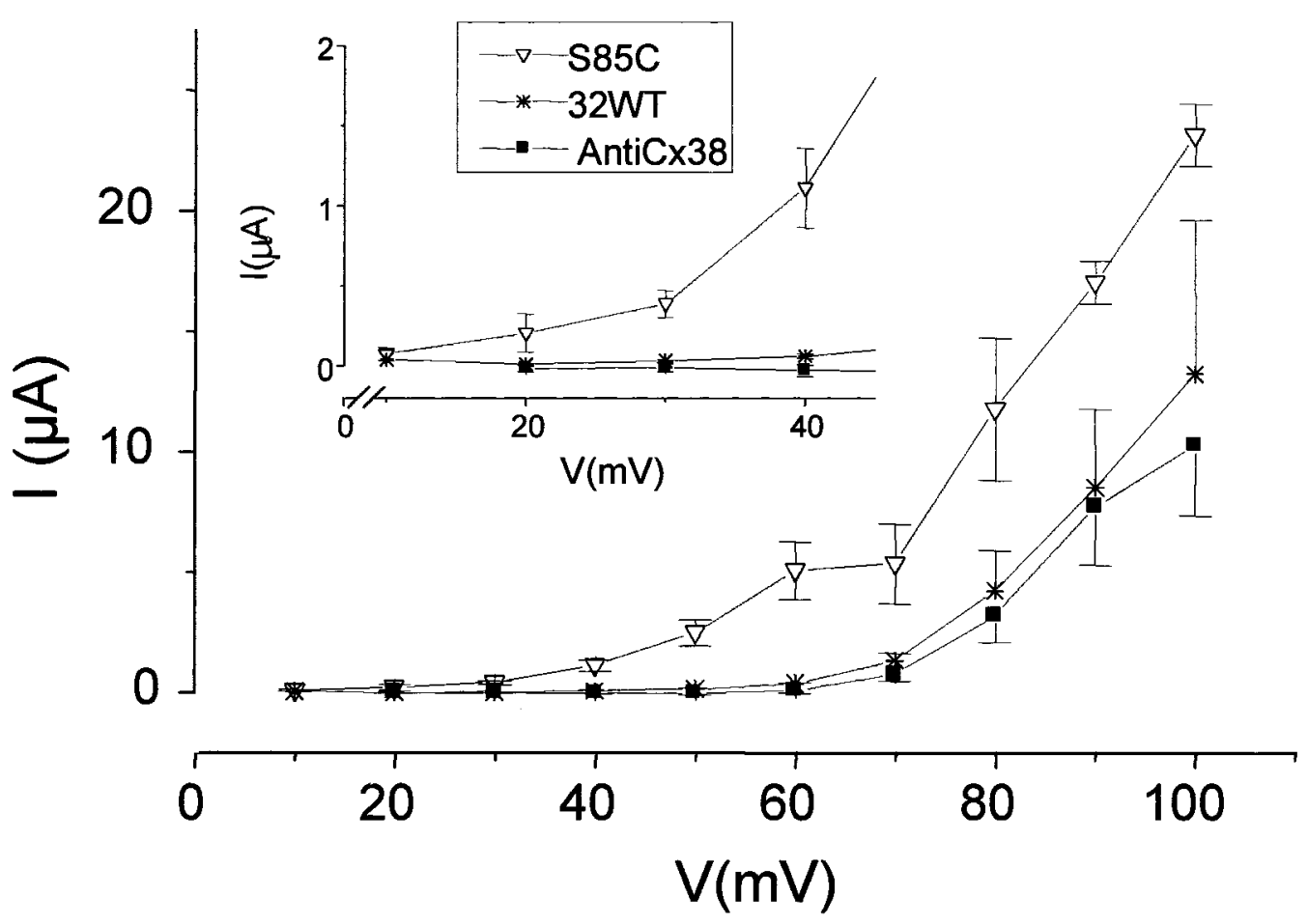

Fig. 2. Current-voltage relations for oocytes injected with antiCx38 or with $0.1 \mu \mathrm{l}$ of a $175 \mathrm{ng} / \mu \mathrm{l}$ solution of mRNA for Cx32(S85C) or Cx32WT. The points for $\mathrm{Cx} 32 \mathrm{WT}(*)$ and $\mathrm{Cx} 32(\mathrm{~S} 85 \mathrm{C})(\nabla)$ are the currents measured at the end of 20 -s pulses from +10 to +80 . Traces for antiCx38 ( $\square$ ) are in response to 20 -s pulses from $-70 \mathrm{mV}$ to voltages ranging from +20 to $+80 \mathrm{mV}$. Activating currents are seen in Cx32(S85C) cells at voltages above $+10 \mathrm{mV}$, whereas both Cx32WT- and AntiCx38-injected cells begin to show outward currents at higher voltages. Although no significant differences between antiCx38- and Cx32WT-injected cells were detected by using the Kruskal-Wallis test with Dunn's post test, the Cx32WT-injected cells did show a trend toward slightly larger outward currents. Each curve is representative of data from at least 19 oocytes (means \pm SEM).

mediating conductance was relatively nonselective. Average currents induced by the end of 20 -s voltage steps from the holding potential of $-70 \mathrm{mV}$ to values from $+10 \mathrm{mV}$ or $+20 \mathrm{mV}$ to $+100 \mathrm{mV}$ for each set of oocytes are shown in Fig. 2 (Inset shows smaller voltages with an expanded current axis). The induced currents are significantly larger for the Cx32(S85C)injected oocytes than for the Cx32WT or antiCx38 oocytes. For example, at $+30 \mathrm{mV}$, the $\mathrm{Cx} 32$ (S85C), Cx32WT, and antiCx38injected cells showed $430 \pm 93 \mathrm{nA}, 35 \pm 6.0 \mathrm{nA}$ and $9.8 \pm 30 \mathrm{nA}$, respectively, whereas at $+70 \mathrm{mV}$ they showed $5.3 \pm 1.7 \mu \mathrm{A}, 1.3 \pm$ $0.31 \mu \mathrm{A}$, and $0.73 \pm 0.27 \mu \mathrm{A}$, respectively. The currents seen in the Cx32WT- and AntiCx38-injected oocytes were not significantly different at any voltage examined, although there was a slight trend toward higher currents in the Cx32WT-injected cells. Thus, currents mediated by Cx32WT hemichannels, if present, seem to contribute little to the overall membrane current. We suggest that the large voltage-dependent currents in oocytes expressing Cx32(S85C) are mediated by functional hemichannels formed by the Cx32 mutant. This inference is supported by the effects of acidification and high $\mathrm{Ca}^{2+}$ described in the next paragraph.

Increase in intracellular $\mathrm{pH}$ has been shown to close most gap junctions and also to close unapposed gap junction hemichannels (44). Reduction in conductance is rapidly reversible for short exposures to low $\mathrm{pH}(44)$. The currents produced by the cells expressing the $\mathrm{Cx} 32$ (S85C) mutant showed this sensitivity to intracellular acidification; Cx32(S85C)-induced currents were reversibly eliminated by short applications of $\mathrm{CO}_{2}$-saturated bath solution $(\approx \mathrm{pH} 5.6$, Fig. $3 A)$. Hemichannel currents in oocytes are reduced at elevated $\mathrm{Ca}^{2+}$ concentrations [Cx46 (45), the chimeric Cx32*43E1 (21), Cx38 (18), and many cells expressing endogenous connexins show hemichannel opening at low $\mathrm{Ca}$ (references in ref. 28)]. The Cx32(S85C)-induced currents showed a similar sensitivity to $\mathrm{Ca}^{2+}$ with a roughly 2.5 -fold increase in current when decreasing bath $\left[\mathrm{Ca}^{2+}\right]$ from $1.8 \mathrm{mM}$ to $200 \mu \mathrm{M}$ (Fig. $3 B$ ) and a similar magnitude decrease on increasing bath $\left[\mathrm{Ca}^{2+}\right.$ ] from $1.8 \mathrm{mM}$ to $5 \mathrm{mM}$ (data not shown).

To examine the possibility that the greater amplitude of Cx32(S85C) hemichannel currents were caused by higher surface expression than for Cx32WT, we used Western blotting of surface and total proteins. We evaluated the levels of $\mathrm{Cx} 32$ (S85C) and Cx32WT protein in oocytes prepared in the same manner as for the electrophysiological measurements. We used an antibody raised against the cytoplasmic loop of Cx32 that would be expected to react to mutant and WT forms equally. The total Cx32 immunoreactivity was between 2- and 4-fold greater in Cx32WT-expressing oocytes than in Cx32(S85C)-expressing oocytes (Fig. $4 A$ ). Furthermore, the amounts of immunoreactive protein in the surface membrane isolated by biotinylation were much higher for oocytes expressing Cx32WT than for those expressing Cx32(S85C) (Fig. 4B). In fact, the surface-labeled protein containing the S85C mutation was barely detectable. These data indicate that the increased hemichannel currents associated with $\mathrm{Cx} 32$ (S85C) are caused by increased open probability rather than the insertion of a greater number of hemichannels into the surface membrane. Although we cannot entirely rule out differential solubilization of Cx32WT and $\mathrm{Cx} 32$ (S85C) during homogenization of the oocytes, it is unlikely that such an effect would account for the differences shown here.

\section{Discussion}

In this paper, we describe formation of hemichannels by a mutant Cx32 associated with CMTX disease. Gap junction hemichannel formation has been described for several other connexins that have been studied in Xenopus oocytes, including Cx38 (18, 19), Cx46 (20), the chimeric Cx32*43E1 (21, 23), Cx50 


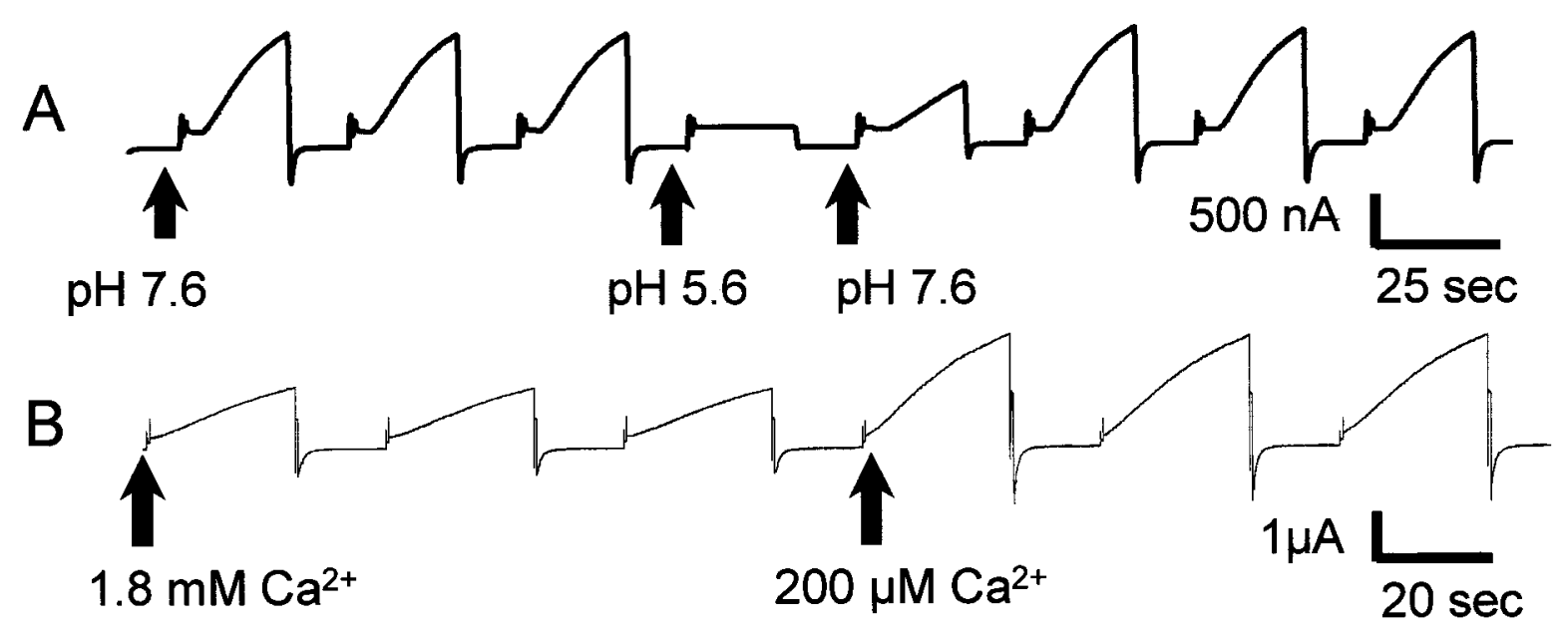

Fig. 3. Properties of $\mathrm{Cx} 32(\mathrm{~S} 85 \mathrm{C})$ hemichannels. (A) Effect of acidification on voltage-activated currents in oocytes injected with mRNA for Cx32(S85C). An oocyte bathed in MND96 with $\mathrm{Ca}^{2+}$ was pulsed between $-70 \mathrm{mV}$ and $+30 \mathrm{mV}$. After the third pulse (at the second arrow), the bath was perfused with $\mathrm{CO}_{2}$-saturated MND96 with $\mathrm{Ca}^{2+}$, which caused a rapid and complete loss of voltage-activated current. The conductance recovered when the bath was perfused with control MND96 with $\mathrm{Ca}^{2+}$ (third arrow). (B) Effect of reduced-bath $\mathrm{Ca}^{2+}$ on voltage-activated currents in oocytes injected with mRNA for Cx32(S85C). A single oocyte bathed in MND96 with $1.8 \mathrm{mM} \mathrm{Ca}^{2+}$ was pulsed between $-70 \mathrm{mV}$ and $+30 \mathrm{mV}$. After the third pulse (at the second arrow), the bath was perfused with MND96 with $200 \mu \mathrm{M} \mathrm{Ca}^{2+}$, with a resulting 2 1/2-fold increase in magnitude of voltage-evoked current.

(24), and Cx56 (25). Also, Cx32WT has been reported to produce functional hemichannels in Xenopus oocytes (26). In the discussion by Castro et al. (26), they raise the possibility that increased opening of Cx32 hemichannels is a potential pathogenic mechanism for CMTX. The differences between our findings and theirs are difficult to interpret because of the similarity of both the magnitude and shape of the Cx32WT currents shown in that article and the currents seen in our oocytes injected only with antiCx38. The small quantitative

A

TOTAL PROTEIN FROM INJECTED OOCYTES

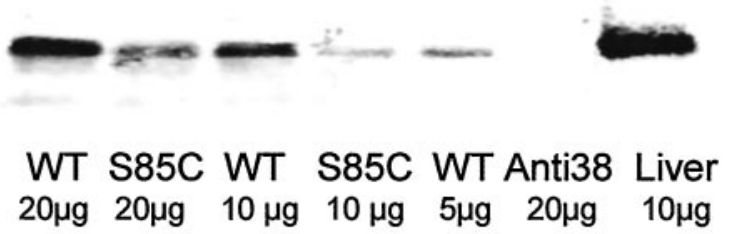

\section{B SURFACE PROTEIN FROM INJECTED OOCYTES}

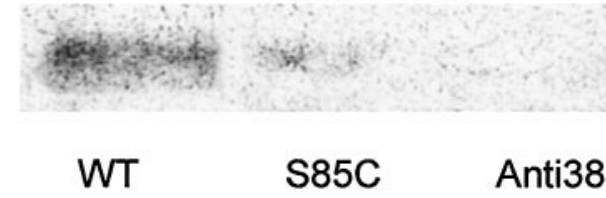

Fig. 4. Expression of $\mathrm{C} \times 32$ (S85C) in oocytes is lower than that of $\mathrm{C} \times 32 \mathrm{WT}$. (A) Western blot analysis of total protein extracts from 13 pooled oocytes injected with mRNA for Cx32(S85C), mRNA for Cx32WT, or antiCx38 alone. The blot was probed with antibody to $\mathrm{Cx} 32$, as described in Methods. As shown, the levels of $\mathrm{C} \times 32$ protein in the $\mathrm{C} \times 32$ (S85C)-injected oocytes are between $1 / 2$ and $1 / 4$ that of the Cx32WT-injected oocytes. $(B)$ Western blot analysis of surfacemembrane protein extracts from the same oocytes shown in $A$ [mRNA for Cx32(S85C), mRNA for Cx32WT, or antiCx38 alone]. Membrane proteins were isolated by reacting intact oocytes with the membrane impermeant reagent NHS-S-S-Biotin and recovered with neutravidin-coated beads (see Methods). The amount of protein in the membrane was substantially greater for Cx32WT than for Cx32(S85C). difference in levels of membrane current that we observed between Cx32WT-and antiCx38-injected cells could have arisen if Cx32WT forms a functional hemichannel with low efficiency and/or low open probability; however, in our hands, this difference is much too small to be convincingly attributed to a hemichannel current. Unopposed gap junction hemichannels can also form functional ion channels in a number of different primary cell types including astrocytes $(22,27,28)$, normal rat kidney (29), toad bladder epithelium (30), and cardiac myocytes $(31,32)$. Hemichannels can open under near-physiological conditions and may play a role in paracrine signaling $(33,34)$, propagation of $\mathrm{Ca}^{2+}$ waves (35), isosmotic volume regulation (36), and normal retinal functioning $(37,38)$. Indeed, there is growing evidence that functional gap junction hemichannels may play a role in both normal functions and in pathologic states.

Expression of the Cx32(S85C) mutant in Xenopus oocytes leads to large hemichannel-mediated voltage-dependent membrane currents not seen in oocytes expressing Cx32WT or in oocytes injected with antiCx38 alone. The currents mediated by Cx32(S85C) hemichannels exhibit a number of properties commonly associated with the hemichannels including slow, voltagedependent gating to the open state and reduction by intracellular acidification or by increase in extracellular $\mathrm{Ca}^{2+}$ concentration. The currents arise in oocytes with reduced surface expression of Cx32(S85C) compared with surface expression of Cx32WT; thus, the increased currents can be ascribed to increases in open probability in response to inside positivity. The increased open probability may be caused by an alteration in the intrinsic voltage sensitivity of the hemichannel, making it more sensitive to depolarization-induced opening; alternatively, the $\mathrm{Cx} 32$ (S85C) mutation may induce a voltage-independent conformational change that converts the hemichannel to a voltage-activatable state, either rarely or never entered by the WT channel.

Regardless of the mechanism leading to opening of Cx32(S85C) hemichannels, the ability to form functional hemichannels is likely to represent a toxic gain of function, because the presence of open hemichannels in the Schwann cell membrane would likely have detrimental consequences in terms of collapse of ionic gradients, loss of metabolites, and influx of $\mathrm{Ca}^{2+}$. Although the open probability of a single Cx32(S85C) hemichannel is likely to be very low at the resting potential of a Schwann cell, depolarization of the cell by metabolic stress or 
action potential propagation, when local extracellular $\mathrm{K}^{+}$concentration increases, would increase this open probability. In addition, although the open probability of an individual Cx32(S85C) hemichannel might remain low under the conditions noted above, even a small number of open hemichannels might damage Schwann cells, which have a high-input resistance. The input resistance of cultured Schwann cells in the whole-cell patch-clamp configuration is $3.6 \pm 0.72 \mathrm{G} \Omega(n=17)$ (unpublished observations). Because of shunting around the patchclamp seal, the actual input resistance may be higher. Thus, only a few hemichannels of $\approx 100 \mathrm{pS}$ could cause a substantial leak. Because the opening of hemichannels would likely contribute to membrane depolarization, hemichannel opening may in fact be a regenerative process, although the reversal potential in oocytes is below the level that leads to easily measured increase in hemichannel currents.

A toxic gain of function such as that proposed here for the Cx32(S85C) mutant might lead to an unusually severe form of CMTX. In fact, such a gain of function might be predicted to affect other cells in which Cx32 is expressed, including hepato-

1. Bergoffen, J., Scherer, S. S., Wang, S., Scott, M. O., Bone, L. J., Paul, D. L., Chen, K., Lensch, M. W., Chance, P. F. \& Fischbeck, K. H. (1993) Science 262, 2039-2042.

2. Scherer, S. S., Deschenes, S. M., Xu, Y. T., Grinspan, J. B., Fischbeck, K. H. \& Paul, D. L. (1995) J. Neurosci. 15, 8281-8294.

3. Nicholson, S. M., Gomes, D., de Nechaud, B. \& Bruzzone, R. (2001) J. Neurosci. Res. 66, 23-36.

4. Oh, S., Ri, Y., Bennett, M. V. L., Trexler, E. B., Verselis, V. K. \& Bargiello, T. A. (1997) Neuron 19, 927-938.

5. Bevans, C. G., Kordel, M., Rhee, S. K. \& Harris, A. L. (1998) J. Biol. Chem. 273, 2808-2816.

6. Niessen, H. \& Willecke, K. (2000) FEBS Lett. 466, 112-114.

7. Ionasescu, V. V., Searby, C., Ionasescu, R., Neuhaus, I. M. \& Werner, R. (1996) Neurology 47, 541-544.

8. Ionasescu, V., Searby, C. \& Ionasescu, R. (1994) Hum. Mol. Genet. 3, 355-358.

9. Ainsworth, P. J., Bolton, C. F., Murphy, B. C., Stuart, J. A. \& Hahn, A. F. (1998) Hum. Genet. 103, 242-244.

10. Nakagawa, M., Takashima, H., Umehara, F., Arimura, K., Miyashita, F., Takenouchi, N., Matsuyama, W. \& Osame, M. (2001) J. Neurol. Sci. 185, 31-37.

11. Hahn, A. F., Ainsworth, P. J., Naus, C. C., Mao, J. \& Bolton, C. F. (2000) Muscle Nerve 999, S39-S48.

12. Deschenes, S. M., Walcott, J. L., Wexler, T. L., Scherer, S. S. \& Fischbeck, K. H. (1997) J. Neurosci. 17, 9077-9084.

13. Abrams, C. K., Freidin, M. M., Verselis, V. K., Bennett, M. V. L. \& Bargiello, T. A. (2001) Brain Res. 900, 9-25.

14. VanSlyke, J. K., Deschenes, S. M. \& Musil, L. S. (2000) Mol. Biol. Cell 11, 1933-1946.

15. Fischbeck, K. H., Abel, A., Lin, G. S. \& Scherer, S. S. (1999) Ann. N.Y. Acad. Sci. 883, 36-41.

16. Bruzzone, R., White, T. W., Scherer, S. S., Fischbeck, K. H. \& Paul, D. L. (1994) Neuron 13, 1253-1260.

17. Bennett, M. V. L., Barrio, L. C., Bargiello, T. A., Spray, D. C., Hertzberg, E. \& Saez, J. C. (1991) Neuron 6, 305-320.

18. Ebihara, L. (1996) Biophys. J. 71, 742-748.

19. Ebihara, L. \& Steiner, E. (1993) J. Gen. Physiol. 102, 59-74.

20. Trexler, E. B., Bennett, M. V. L., Bargiello, T. A. \& Verselis, V. K. (1996) Proc. Natl. Acad. Sci. USA 93, 5836-5841.

21. Pfahnl, A., Zhou, X. W., Werner, R. \& Dahl, G. (1997) Pflügers Arch. 433, 773-779.

22. Hofer, A. \& Dermietzel, R. (1998) Glia 24, 141-154.

23. Oh, S., Abrams, C. K., Verselis, V. K. \& Bargiello, T. A. (2000) J. Gen. Physiol. 116, 13-31.

24. Zampighi, G. A., Loo, D. D., Kreman, M., Eskandari, S. \& Wright, E. M. (1999) J. Gen. Physiol. 113, 507-524.

25. Ebihara, L., Berthoud, V. M. \& Beyer, E. C. (1995) Biophys. J. 68, 1796-1803.

26. Castro, C., Gomez-Hernandez, J. M., Silander, K. \& Barrio, L. C. (1999) J. Neurosci. 19, 3752-3760.

27. Verderio, C., Bruzzone, S., Zocchi, E., Fedele, E., Schenk, U., De Flora, A. \& Matteoli, M. (2001) J. Neurochem. 78, 646-657. cytes (46), pancreatic acinar cells (47), and oligodendrocytes (2). Dysfunction of these cells might, in turn, lead to clinically recognizable manifestations. No pathology has been noted in human liver or pancreatic function in patients with CMTX, although there is some alteration of function in Cx32 knockout mice (48-51). Unfortunately, this hypothesis cannot be tested because the clinical data on the Cx32(S85C) mutation is limited (there is a paucity of data, contributed to, perhaps, by the severity of the phenotype). There is a need to examine other mutations associated with CMTX for hemichannel formation (in Schwann cells as well as oocytes) and to determine whether there is a correlation between disease severity and hemichannel formation.

We thank Angela Bukauskiene, Geng Qui Liu, and Judy Wong for their excellent technical assistance. This work was supported by National Institutes of Health Grant 1K08 NS 02149-01 and a Muscular Dystrophy Association Research grant (to C.K.A.). Dr. Michael V. L. Bennett is the Sylvia and Robert S. Olnick Professor of Neuroscience and is supported by National Institutes of Health Grant NS 05712 and a grant from the Kirby Foundation.

28. Contreras, J. E., Sanchez, H. A., Eugenin, A. E., Speidel, D., Theis, M., Willecke, K., Bukauskas, F. F., Bennett, M. V. L. \& Saez, J. C. (2002) Proc. Natl. Acad. Sci. USA 99, 495-500.

29. Li, H., Liu, T. F., Lazrak, A., Peracchia, C., Goldberg, G. S., Lampe, P. D. \& Johnson, R. G. (1996) J. Cell Biol. 134, 1019-1030.

30. Vanoye, C. G., Vergara, L. A. \& Reuss, L. (1999) Am. J. Physiol. 276, C279-C284.

31. John, S. A., Kondo, R., Wang, S. Y., Goldhaber, J. I. \& Weiss, J. N. (1999) J. Biol. Chem. 274, 236-240.

32. Kondo, R. P., Wang, S. Y., John, S. A., Weiss, J. N. \& Goldhaber, J. I. (2000) J. Mol. Cell. Cardiol. 32, 1859-1872.

33. Bruzzone, S., Guida, L., Zocchi, E., Franco, L. \& De Flora, A. (2001) FASEB J. 15, 10-12.

34. Franco, L., Zocchi, E., Usai, C., Guida, L., Bruzzone, S., Costa, A. \& De Flora, A. (2001) J. Biol. Chem. 276, 21642-21648.

35. Cotrina, M. L., Lin, J. H., Alves-Rodrigues, A., Liu, S., Li, J., Azmi-Ghadimi, H., Kang, J., Naus, C. C. \& Nedergaard, M. (1998) Proc. Natl. Acad. Sci. USA 95, 15735-15740.

36. Quist, A., Rhee, S., Lin, H. \& Lal, R. (2000) J. Cell Biol. 148, 1063-1074.

37. DeVries, S. H. \& Schwartz, E. A. (1992) J. Physiol. 445, 201-230.

38. Kamermans, M., Fahrenfort, I., Schultz, K., Janssen-Bienhold, U., Sjoerdsma, T. \& Weiler, R. (2001) Science 292, 1178-1180.

39. Valiunas, V. \& Weingart, R. (2000) Pflügers Arch. 440, 366-379.

40. Janssen, E. A., Kemp, S., Hensels, G. W., Sie, O. G., de Die-Smulders, C. E., Hoogendijk, J. E., de Visser, M. \& Bolhuis, P. A. (1997) Hum. Genet. 99, 501-505.

41. Verselis, V. K., Ginter, C. S. \& Bargiello, T. A. (1994) Nature (London) 368, $348-351$.

42. Rubin, J. B., Verselis, V. K., Bennett, M. V. \& Bargiello, T. A. (1992) Proc. Natl. Acad. Sci. USA 89, 3820-3824.

43. Chen, N., Luo, T. \& Raymond, L. A. (1999) J. Neurosci. 19, 6844-6854.

44. Trexler, E., Bukauskas, F. F., Bennett, M. V. L., Bargiello, T. A. \& Versalis, V. K. (1999) J. Gen. Physiol. 113, 721-742

45. Pfahnl, A. \& Dahl, G. (1999) Pflügers Arch. 437, 345-353.

46. Paul, D. L. (1986) J. Cell Biol. 103, 123-134.

47. Meda, P., Pepper, M. S., Traub, O., Willecke, K., Gros, D., Beyer, E., Nicholson, B., Paul, D. \& Orci, L. (1993) Endocrinology 133, 2371-2378.

48. Temme, A., Stumpel, F., Sohl, G., Rieber, E. P., Jungermann, K., Willecke, K. \& Ott, T. (2001) Pflügers Arch. 442, 961-966.

49. Stumpel, F., Ott, T., Willecke, K. \& Jungermann, K. (1998) Hepatology 28, 1616-1620.

50. Chanson, M., Fanjul, M., Bosco, D., Nelles, E., Suter, S., Willecke, K. \& Meda, P. (1998) J. Cell Biol. 141, 1267-1275.

51. Nelles, E., Butzler, C., Jung, D., Temme, A., Gabriel, H. D., Dahl, U., Traub, O., Stumpel, F., Jungermann, K., Zielasek, J., Toyka, K. V., Dermietzel, R. \& Willecke, K. (1996) Proc. Natl. Acad. Sci. USA 93, 9565-9570. 